\title{
Issues of Exporting Rice from Pakistan to India in the context of South Asian Free Trade Agreement (SAFTA)
}

Faiz Muhammad Shaikh

Assistant Professor

SZABAC-Dokri-Larkana-Sindh

Pakistan

Email:faizanmy2000@hotmail.com
Dr.Anwar Ali Shah G.Syed
Pro-Vice Chancellor
Sindh University Campus Dadu
Email:faizanmy2000@hotmail.com
Dr. Muhammad Saleh Memon
Assistant Professor
Deptt: Business Administration
SALU-KhairpurMirs
Dr.Nanik Ram
Professor-Deptt: of Economics
University of Sindh_Jamshoro

\begin{abstract}
This research investigates the issues of Textile exporters in the context of PAK-India trade relation. Data were collected from 100 exporters by using simple random technique. Data were analyzed by using SPSS-20 version;a structural questionnaire was developed for the reliability and validity of the data. It was revealed that the tariff barrier might below due to several rounds of GATT and WTO. It was further revealed major barriers but cultural one, the currency exchange rate and informational barrier end to be the major barriers to export. The Legal and Political barriers, Languages and Customs, demand of the product, working structure/schedule of the targeting country, business environment are not regarded as barriers to export.
\end{abstract}

Key Words: ISSUES; PAK-INDIA; TRADE.

\section{Council for Innovative Research}

Peer Review Research Publishing System

Journal: International Journal Of Management \& Information Technology

Vol . 10, No 6

editorsijmit@gmail.com

$\underline{\text { www.ijmit.com }}$ 


\section{Introduction}

Rice is a staple for the majority of the 1.7 billion South Asian populations and a source of livelihood for more than 50 million households. Apart from its economic and strategic importance, rice is deeply engraved in the rich tradition and culture of many South Asian countries. In India and Nepal, rice offerings to bring good health and prosperity to family members are common on many auspicious occasions. The significance of rice extends beyond life for Hindu communities in the region with offerings given to the departed soul. Similarly, in Sri Lanka, during the marriage ceremony, known as Poruwa, the bride and groom are placed on the top of paddy to bring fertility to the couple. One can find many religious and cultural uses of rice or paddy throughout South Asia.

The region cultivates rice on 60 million hectares and produces slightly above 225 million tons of paddy, accounting for $37.5 \%$ of the global area and $32 \%$ of global production in 2013. Within South Asia, both India and Bangladesh are major rice-growing countries. India has the largest rice area in the world with 43 million hectares (more than a quarter of the global rice area) and contributes a little less than a quarter of global production. Bangladesh has more than 11 million hectares of rice area and produces 50 million tons of paddy.

\section{Literature Review}

Siriwardana(2001) using version 4GTAP database focuses on bilateral trade liberalization between SriLanka and SAARC countries and the implications for Sri Lanka. It conducted 12 trade liberalization related experiments between SAARC countries, ASEAN countries and other Asian countries. The result soft his study suggest that SriLanka would benefit from bilateral trade liberalization between SriLanka and SAARC countries. SriLanka would benefit further by expanding bilateral trade liberalization into ASEAN and other Asian countries. However, the results were mixed in terms of detailed commodity-wise analysis. De Rosa and Goninan(1995,1996)evaluate three possible policy options for South Asia First, the implications of SAPTA by looking at the effect so $f$ removal of tariff sand Para- tariff so nintra-region al imports; second, The implications of close re conomicties between SAARC and APEC countries by looking at removal of trade barriers between the two regions; and third, the implications of un ilateral trade liberalization in South Asia. The results support SAPTA in terms of an increase in food trade. However, this study suggests that SAARC countries might achieve much larger gains in trade and welfare by intensifying efforts to integrate the South Asian economies with the world economy. This study found that the net trade creation of SAPTA was limited due to extensive trade diversification. Samaratunga (1999) investigated the effects of SAARC-APEC trade links and found that the potential for export expansion of the SAARC region into APEC countries is limited within the1991-1995policyframework.

Bandara and Yu (2003) applied the CGE model with version5 of GTAP data base and conducted a series of policy simulations to answer the question of how desirable South Asian Free Trade Area is ? These policy simulations are related to u $\mathrm{n}$ il a t e r a I trade liberalization by South Asia; preferential trade liberalization in South Asia; preferential trade liberalization between South Asia and ASEAN, NAFTA, EU; and multi-trade liberalization. The results suggest that the impact of preferential trade liberalization is very small, but that the impact of un ilateral trade liberalization is significant for South Asian countries. Under preferential trade liberalization, small countries would lose or gain marginally. Daniel(2007) evaluates the SAFTA within the global structure of over lapping RTA s using modified gravity equation. First, it examines the effects of the Trade Liberalization Program (TLP), w h i c h started in 2006. SAFTA would have a minor effect on regional trade flows and the impact on custom duties would be a manageable fiscal shock for most members. Second, the paper ranks the trade effects of other potential RTAs for individual South Asian countries and SAFTA: RTAs with North American Free Trade Agreement (NAFTA) and the European Union(EU)dominate one with the Association of South East Asian Nations (ASEAN).

Bays an, et al. (2006) conclude that, considered in isolation, the economic case for SAFTA is quite weak. When compared with the rest of the world, the region is tiny both in terms of economic size as measured by GDP (and per capita in comes) and the share in the world trade.It is argued that primafacie, the sefacts make it likely that trade diversion would be dominant as a result of SAFTA. This point is reinforced by the presence of high levels of protection in the region and the tendency of the member countries to establish highly restrictive 'sector al exceptions/sensitive lists 'and stringent 'rules of origin'. They further argue that SAFTA makes sense only in the context of a much broader strategy of creating a larger preferential trade area in the region that specifically would encompass China and the member nations of the Association of South East Asian Nations. In turn, the case for the latter is strategic; the pursuit of regional is $\mathrm{min}$ the Americas and Europe has created increasing discrimination against 


\section{MAJOR ISSUES ON SAFTA BY RICE EXORTERS OF PAKISTAN}

The Cronbach alpha test was applied for reliability and internal consistency of the multiitembarrierscaleonallbarriers. Theinternalconsistencyofthequestionnairewas checked by this test.

Table1.ReliabilityStatistics

\begin{tabular}{|l|l|l|}
\hline Cronbach'salpha & Cronbach'salphabasedonstandardizeditems & Nofitems \\
\hline .887 & .889 & 30 \\
\hline
\end{tabular}

From Table 1 one can see that the Cron bach alpha value is 0.98 , which is considered to have a very high internal consistency and reliability. So, it was concluded that the scales for the multi- item barrier questions were very reliable and had an internal consistence

Table-1-Exporters'perceptionofbarriersduringexport/Natureofproblemfaced by Pakistani exporters during export to the INDIA

\section{One-samplet-test}

Table2.One-samplet-test

\begin{tabular}{|c|c|c|c|c|c|c|}
\hline Barrier & \multirow{2}{*}{\begin{tabular}{|l|} 
\\
60
\end{tabular}} & \multirow{2}{*}{\begin{tabular}{|l|} 
Mean \\
3.0667 \\
\end{tabular}} & \multirow{2}{*}{\begin{tabular}{|l}
$\begin{array}{l}\text { Std. } \\
\text { deviation }\end{array}$ \\
1.19131 \\
\end{tabular}} & \multirow{2}{*}{\begin{tabular}{|l} 
t-value \\
7.196 \\
\end{tabular}} & \multirow{2}{*}{$\begin{array}{l}\text { Sig. } \\
\text { (2-tailed) } \\
.000\end{array}$} & \multirow{2}{*}{\begin{tabular}{|l|} 
Sig.at \\
.05 \\
Yes
\end{tabular}} \\
\hline Tariff barrier & & & & & & \\
\hline Governmentalregulations & 60 & 3.4667 & 1.25505 & 9.299 & .000 & Yes \\
\hline Priceofthecommodity & 60 & 2.5833 & 1.12433 & 4.294 & .000 & Yes \\
\hline Marketaccessproblem & 60 & 3.5000 & 1.44386 & 8.262 & .000 & Yes \\
\hline Informationalbarrier & 60 & 3.0667 & 1.26044 & 6.801 & .000 & Yes \\
\hline LegalandPoliticalbarriers & 60 & 2.4000 & 1.06086 & 3.213 & .002 & Yes \\
\hline Customprocedureandlicensing. & 60 & 3.5000 & 1.30838 & 9.117 & .000 & Yes \\
\hline Technicalstandards andhealthregulations & 60 & 4.1000 & 1.18893 & 13.942 & .000 & Yes \\
\hline Anti-dumping & 60 & 3.1000 & 1.50367 & 5.873 & .000 & Yes \\
\hline Languagesandcustoms & 60 & 3.0167 & .96536 & 8.479 & .000 & Yes \\
\hline Culture & 60 & 2.8500 & 1.32544 & 5.201 & .000 & Yes \\
\hline Labelingandpackagingrequirement & 60 & 4.0333 & 1.05713 & 15.192 & .000 & Yes \\
\hline Sanitaryandphytosanitary(SPS)measures & 60 & 3.9500 & 1.06445 & 14.481 & .000 & Yes \\
\hline Importquotasofdestinationcountry & 60 & 2.4333 & 1.14042 & 3.215 & .002 & Yes \\
\hline Demandoftheproduct & 60 & 2.7000 & 1.19745 & 4.787 & .000 & Yes \\
\hline Competitionfromfirmsinforeignmarkets & 60 & 2.5833 & 1.23908 & 3.897 & .000 & Yes \\
\hline $\begin{array}{l}\text { Lackofcapitaltofinanceexpansio } \\
\text { ninto foreignmarkets }\end{array}$ & 60 & 2.9667 & 1.22082 & 6.387 & .000 & Yes \\
\hline Businessenvironment & 60 & 2.6000 & 1.06086 & 4.673 & .000 & Yes \\
\hline Industrialpropertyrightsandcopyrights & 60 & 2.7333 & 1.27381 & 4.703 & .000 & Yes \\
\hline Corruption & 60 & 2.6167 & 1.27680 & 3.984 & .000 & Yes \\
\hline Currency exchangerate & 60 & 3.2667 & 1.19131 & 8.496 & .000 & Yes \\
\hline Climaticconditionsofdestinationcountry & 60 & 2.0500 & 1.01556 & .686 & .495 & No \\
\hline Transportationcostandduration & 60 & 2.7833 & 1.23634 & 5.158 & .000 & Yes \\
\hline Certification & 60 & 3.3167 & 1.26881 & 8.282 & .000 & Yes \\
\hline $\begin{array}{l}\text { Workingstructure/scheduleofthetargetin } \\
\text { g country }\end{array}$ & 60 & 1.6667 & .83700 & -2.715 & .009 & Yes \\
\hline
\end{tabular}

Table-2 The above table shows the various barriers on exporting Rice to SAFTA countries specially India. According to exporters viewpointthatPakistaniexportershavesignificant cope all the above barriers accepttheclimaticconditions. 


\subsection{Percentage analysis}

Percentage analysis has been done to check the strength of each significant barrier. These barriers are divided into two parts - common barriers to export and hidden barriers. Common barriers are those that exist due to governmental regulations and policies and on.

Which global organizations such as WTO find a solution, and they can solve through the agreements. Hidden barriers are those that exist naturally, and government bodies cannot really make solutions on them, but these hidden barriers can affect export negatively.

\section{Common barriers}

Table3.Percentageanalysis of Pakistani exporters' perception of common barriers

\begin{tabular}{|l|l|l|l|l|l|l|}
\hline No. & Commonbarriers & $\begin{array}{l}\text { Notanissue } \\
\text { atall(1) }\end{array}$ & $\begin{array}{l}\text { Nobarrier } \\
(2)\end{array}$ & $\begin{array}{l}\text { Notseenas } \\
\text { barrier(3) }\end{array}$ & Barrier(4) & $\begin{array}{l}\text { Veryserious } \\
\text { barrier(5) }\end{array}$ \\
\hline 1. & Tariff & $5 \%$ & $37 \%$ & $20 \%$ & $23 \%$ & $15 \%$ \\
\hline 2. & $\begin{array}{l}\text { Governmentalregulatio } \\
\text { Customsprocedurea } \\
\text { nd }\end{array}$ & $10 \%$ & $15 \%$ & $13 \%$ & $42 \%$ & $20 \%$ \\
\hline 3. & $7 \%$ & $17 \%$ & $25 \%$ & $30 \%$ \\
\hline 4. & Anti-dumping & $17 \%$ & $25 \%$ & $12 \%$ & $20 \%$ & $27 \%$ \\
\hline 5. & $\begin{array}{l}\text { Technicalstandards } \\
\text { andhealthregulations }\end{array}$ & $5 \%$ & $10 \%$ & $8 \%$ & $30 \%$ & $47 \%$ \\
\hline 6. & $\begin{array}{l}\text { Sanitaryandphytosanit } \\
\text { ary measures }\end{array}$ & $2 \%$ & $13 \%$ & $8 \%$ & $42 \%$ & $35 \%$ \\
\hline 7. & $\begin{array}{l}\text { Importquotaof } \\
\text { destinationcount }\end{array}$ & $23 \%$ & $33 \%$ & $25 \%$ & $13 \%$ & $5 \%$ \\
\hline 8. & $\begin{array}{l}\text { Industrialpropertyright } \\
\text { s andcopyrights }\end{array}$ & $20 \%$ & $27 \%$ & $23 \%$ & $20 \%$ & $10 \%$ \\
\hline 9. & Certification & $10 \%$ & $20 \%$ & $17 \%$ & $35 \%$ & $18 \%$ \\
\hline 10. & Priceofthecommodity & $20 \%$ & $27 \%$ & $33 \%$ & $15 \%$ & $5 \%$ \\
\hline
\end{tabular}

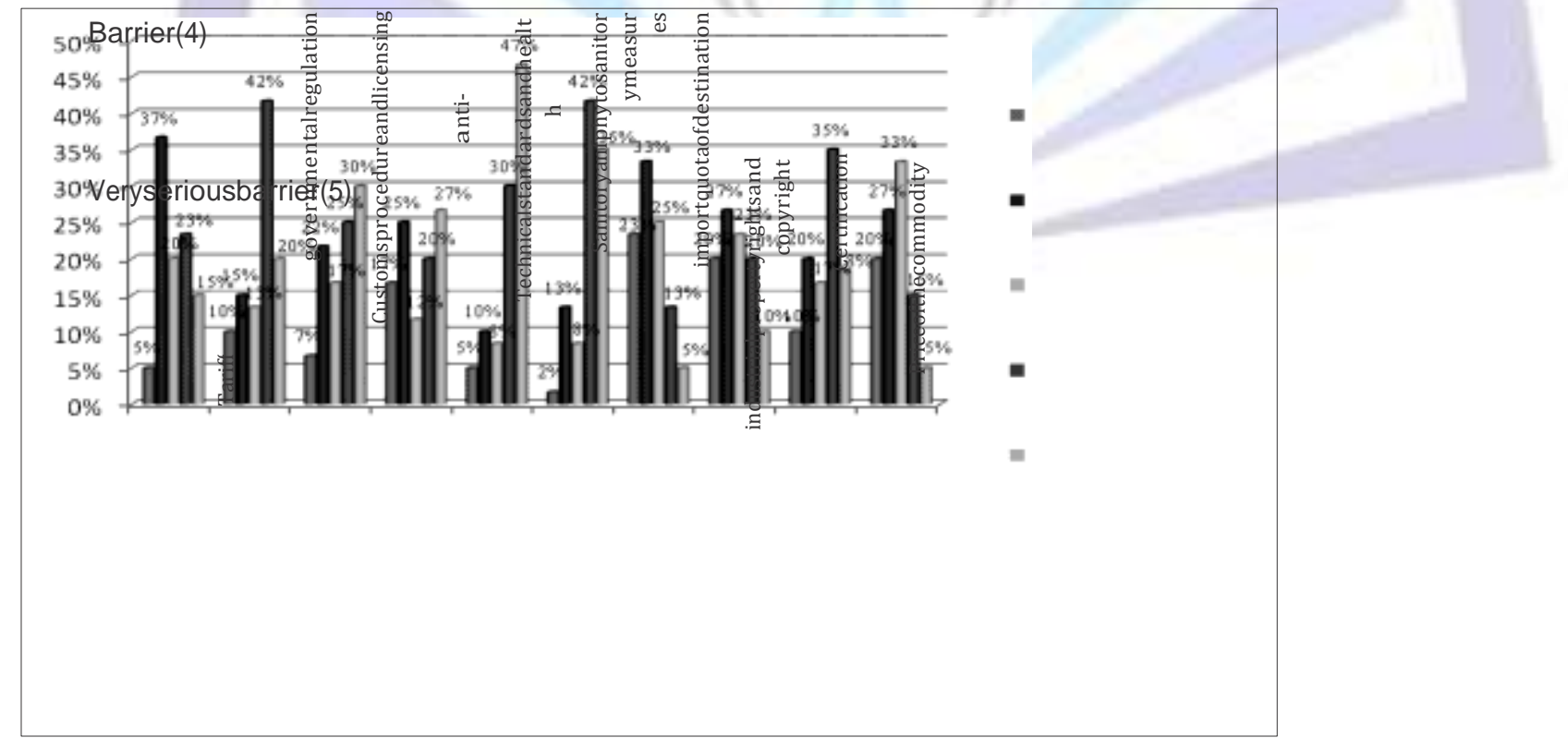

Fig.2.PercentageanalysisofPakistaniexporters'perceptionofcommonbarriers 
Table 3 and Fig. 2 show that respondents regard governmental regulations, customs procedure and licensing, technical standards and health regulations, sanitary and phyto sanitary measures and certification as the major barriers to export. The anti-dumping and tariff barrier are not the major barriers but tends to be the major ones. The tariff barrier may below due to several rounds of GATT and Wots. The import quota of the destination country and the Price of the commodity are not regarded as barriers, either.

\section{Hidden barriers}

Table4.PercentageanalysisofPakistaniexporters'perceptionofhiddenbarriers

\begin{tabular}{|c|c|c|c|c|c|c|}
\hline No & Hiddenbarriers & $\begin{array}{l}\text { Notanissue } \\
\text { atall(1) }\end{array}$ & $\begin{array}{l}\text { Nobarrier } \\
\text { (2) }\end{array}$ & $\begin{array}{l}\text { Notseenas a } \\
\text { barrier(3) }\end{array}$ & $\begin{array}{l}\text { Barrier } \\
\text { (4) }\end{array}$ & $\begin{array}{l}\text { Veryserious } \\
\text { barrier(5) }\end{array}$ \\
\hline 1. & Marketaccessproblem & $13 \%$ & $17 \%$ & $10 \%$ & $27 \%$ & $33 \%$ \\
\hline 2. & Informationalbarrier & $13 \%$ & $23 \%$ & $18 \%$ & $33 \%$ & $12 \%$ \\
\hline 3. & Legalandpolitical barriers & $25 \%$ & $27 \%$ & $33 \%$ & $13 \%$ & $2 \%$ \\
\hline 4. & Languagesandcusto & $5 \%$ & $23 \%$ & $43 \%$ & $22 \%$ & $7 \%$ \\
\hline 5. & Culture & $17 \%$ & $32 \%$ & $15 \%$ & $23 \%$ & $13 \%$ \\
\hline 6. & Demandoftheproduct & $20 \%$ & $22 \%$ & $35 \%$ & $15 \%$ & $8 \%$ \\
\hline 7. & $\begin{array}{l}\text { Competitionfromthefirmsinthe } \\
\text { foreignmarket }\end{array}$ & $25 \%$ & $23 \%$ & $27 \%$ & $18 \%$ & $7 \%$ \\
\hline 8. & $\begin{array}{l}\text { Lackofcapitaltofinance } \\
\text { expansionintoforeignmark }\end{array}$ & $15 \%$ & $18 \%$ & $33 \%$ & $22 \%$ & $12 \%$ \\
\hline 9. & $\begin{array}{l}\text { Businessenvironment } \\
\text { ofthe targetingcountry }\end{array}$ & $18 \%$ & $25 \%$ & $38 \%$ & $15 \%$ & $3 \%$ \\
\hline 10. & Corruption & $23 \%$ & $30 \%$ & $15 \%$ & $25 \%$ & $7 \%$ \\
\hline 11. & Currency exchangerate & $8 \%$ & $20 \%$ & $23 \%$ & $33 \%$ & $15 \%$ \\
\hline 13. & Transportationcostanddurati & $17 \%$ & $30 \%$ & $20 \%$ & $25 \%$ & $8 \%$ \\
\hline 14. & $\begin{array}{l}\text { Workingstructure/scheduleo } \\
\text { f thetargetingcountry }\end{array}$ & $55 \%$ & $25 \%$ & $18 \%$ & $2 \%$ & $0 \%$ \\
\hline 15. & $\begin{array}{l}\text { Labelingandpa } \\
\text { ckaging regulations }\end{array}$ & $3 \%$ & $7 \%$ & $13 \%$ & $37 \%$ & $40 \%$ \\
\hline
\end{tabular}

Table 4 and Fig. 3 show that the respondents regard the market access problems and label in gand pack aging as the major barriers to export. Although not the major barriers but cultural one, the currency exchange rate and informational barrier tend to be the major barriers to export. The Legal and Political barriers, Languages and Customs, demand of the product, working structure/schedule of the targeting country, business environment are not regarded as barriers to export.

When exporters were asked about the other barriers they face than the above- mentioned common and hidden barriers, most of the respondents said that coordination is another barrier they face mostly during expor 


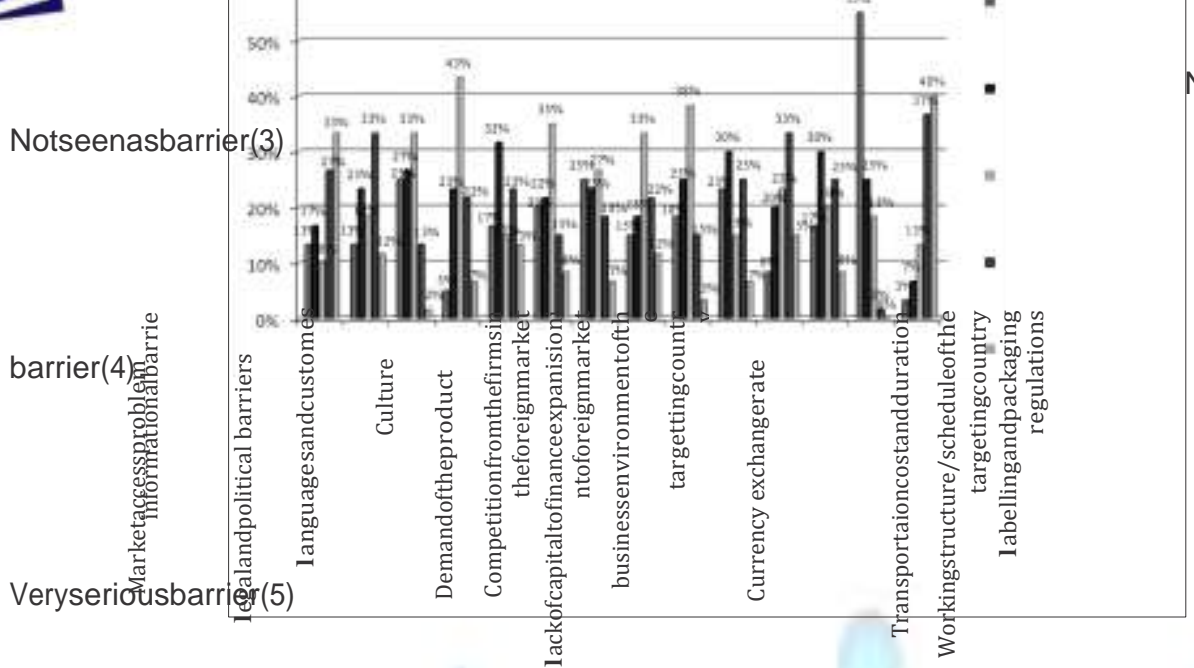

Notanissueatall(1) Nobarriers(2)

Fig3.PercentageanalysisofPakistaniexporters'perceptionofhiddenbarriers

\section{Exporters'attitudeafterdecreasingthestrengthofbarriers}

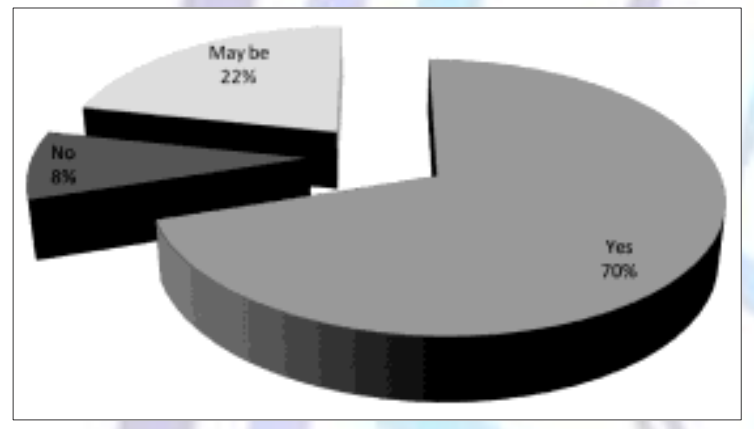

Fig.4.Exporters'opiniononexportafterdecreasingthestrengthofbarriers

Exporters have been askedif they are ready to export more to the INDIA after these barriers will be less, and $70 \%$ of the exporters said yes, $22 \%$ said may be, and $8 \%$ said no. Thus, exporters are positive regarding export to the INDIA. India's export to the INDIA can be increased if these barriers get less or are removed. Exporters can exhibit their

\section{Conclusions}

Governmental regulations, customs procedure and licensing, technical standards and health regulations, sanitary and phyto sanitary measures and certification as the major barriers to export. The anti-dumping and tariff barrier are not the major barriers but tends to be the major ones. The tariff barrier may below due to several rounds of GATT and WTo. The import quota of the destination country and the Price of the commodity are not regarded as barriers, either.

\section{References}

1. Ahmed, S., S. Kelegama, and E. Ghani (2010). Promoting Economic Cooperation in SouthAsia: Beyond SAFTA. Sage Publications, New Delhi.

2. Bandara, J. S. and Yu, W. (2003). "How Desirable is the South Asian Free Trade Area? A Quantitative Economic Assessment." In Greenaway, DS. (ed.) World Economy: GlobalTrade Policy 2003 ,Oxford, U.K.: Blackwell Publishing

3. Baysan, T., Panagariya, A and Pitigala, N. (2006). "Preferential Trading In South Asia", World Bank Policy Research Working Paper 3813, January 2006

4. Bhagwati, J., and Panagariya, A. (1996). "The Theory of Preferential Trade Agreements: Historical Evolution and Current Trends." American Economic Review. 86(2): 82-87. 


\section{ISSN 2278-5612}

5. Coulibaly, S. (2004). "On the Assessment of Trade Creation and Trade Diversion Effects of Developing RTAs," Paper Presented at the Annual Meeting 2005 of the Swiss Society of Economics and Statistics on Resource Economics, Technology, and Sustainable Development. (available at http://www.wif.ethz.ch/resec/sgvs/078.pdf)

5. CUTS, (2012), "Cost of Economic Non-Cooperation to Consumers in South Asia", Working Paper, Consumer Utility Trust Society, Jaipur, India.

6. CUTS, (1996). "Cost of Non-Cooperation to Consumers in the SAARC Countries: An Illustrative Study", Working Paper, Consumer Utility Trust Society, Jaipur, India.

7. Das, S. and Pohit, S. (2006), "Quantifying the Transport, Regulatory and Other Costs of Indian Overland Exports to Bangladesh," The World Economy, Vol. 29, No. 9, 1227- 1242.

8. De, P. and Raihan, S. (2011), "Unlocking India-Bangladesh Trade Potential: Emerging Issues and the Way Forward", paper prepared for the World Bank.

9. DeRosa, D. A. and Govindan, K. (1995). "Agriculture, Trade, and Regionalism in South Asia." Food, Agriculture, and the Environment Discussion Paper 7, Washington, D.C.: International Food Policy Research Institute.

10. Dimaranan, B.V. and R.A. McDougall. Global Trade, Assistance, and Production: The GTAP 5 Data Base, Center for Global Trade Analysis, Purdue University. 2002.

11. Feridhanusetyawan, T. 2005. Preferential Trade Agreements in the Asia-Pacific Region.International Monetary Fund Working Paper 05149. Washington, DC: International Monetary Fund.

12. Ju,JiandongandKalaKrishna.(1998).FirmBehaviorandMarketAccessinaFreeTradeAreawithRulesofOrigin.NBER working Paper, No. 6857.

13. Panagariya,A. (1994).East Asia and theNew Regionalism.World Economy, 17:6, 817-39.

14. Panagariya,A.(1995).RethinkingtheNewRegionalism',PaperPresentedattheUNDPWorldBankTradeExpansion Conference,January,WorldBank,WashingtonDC.

15. Panagariya,A.(2000).PreferentialTradeLiberalization:TheTraditionalTheoryandNewDevelopments. JournalofEconomic Literature,38, June 287-331.

16. Purcell, Garry. (2004a). Analyzing theEconomic Welfare Consequences of A Fare Trade Agreement: Partial EquilibriumMethodsforIndustry LevelStudies, Manuscript Presented atWorld bankDhaka Office.

17. Purcell,Garry.(2004b).AnIndia-BangladeshFreeTradeAgreement?SomePotentialEconomicCostsandbenefits, presented during theworkshop heldatWorldBank, Islamabad Office. 